\title{
Strategy for Increasing Human Resources and Employee Productivity Services in Scientific Education and Training Center Service Malahayati Aceh
}

\author{
Bayu Yudho Baskoro \\ BP2IP Instructor Malahayati Aceh \\ Aceh Besar, Indonesia \\ profcut@unsyiah.ac.id
}

\author{
Cut Zahri Harun \\ Department of Educational Administration \\ Syiah Kuala University, Indonesia \\ profcut@unsyiah.ac.id
}

\author{
Sakdiah Ibrahim \\ Department of Educational Administration \\ Syiah Kuala University, Indonesia \\ profcut@unsyiah.ac.id
}

\begin{abstract}
The purpose of this research is to find out: the formulation of the program, the implementation of the strategy, and the constraints faced by the principal in carrying out the program in improving staffing services. This study uses descriptive method with a qualitative approach. Data collection techniques: observation, interviews, and documentation studies. This research sub-head is the head of the office, sub-division and staff. The results of this study indicate that: (1) the principal program in improving staffing services, the formulation begins with monitoring or analysis carried out by the head of the hall, Head of Subdivision, Internal Supervisor, and Instructors. Programs compiled, long-term programs, all these programs are guided by the regulations of the Ministry of Education and Culture and the applicable curriculum regulations; all of this is already in the head office strategy set out in the head office program to improveservices; (2) when the school carries out a strategy to improve service by means of the head of the hall applying that management to oneself as an example for his subordinates and the head of the hall takes approaches to improve staffing services; and (3) the ambitions faced by the head of the hall in improving staffing services consist of strong local wisdom; and far from the city.
\end{abstract}

Keywords: strategy, head of the center, service personnel

\section{INTRODUCTION}

At every level, types and paths of education certainly have elements of education personnel and education personnel. Educators in universities or education centers are employees who serve as teaching staff or lecturers who are sometimes also given additional structural duties, while education personnel are employees or employees tasked with carrying out administration, management, development, supervision and technical services to support the education process in education units.

Education staff or employees are in charge of sharing things related to the achievement of organizational goals, both short, medium and long term goals, by creating effective and efficient business in completing each job. Employee development is an effort to reduce or eliminate the gap between the capabilities of employees and those desired by the organization. Efforts to improve service capabilities or employee work can be done by increasing knowledge, skills and changing attitudes, so that it can become the most valuable wealth for the organization, because with all its potential, employees can continue to be trained and developed, so that they can be more efficient and accomplished optimal in achieving organizational goals.

In addition to the Shipping Science Education and Training Center, in the leadership of the principal also must be a motivator for staff and education personnel. Murniati and Yusrizal (2014) said the role and function of school principals as motivators is to provide motivation to all school residents so that they can carry out tasks properly in the school.
Makawimbang (2013) says leaders are required to be able to encourage enthusiasm, use the values, beliefs and needs of subordinates to complete tasks and be able to do in situational very fast changing or crisis-filled situations, in other words able to display or create charismatic leadership. full of inspiration, intellectual stimulation and the feeling that each subordinate is taken into account. So every leader must have intellectual intelligence in order to be able to know how the character of his subordinates and have a good role model so as to be able to embrace all his subordinates.

Success or failure of a leader in an organization is strongly influenced by the level of ability to understand the causes that are constraints so that employees are not passionate and enthusiastic in carrying out their work and what is the motive of employees want to work optimally to achieve organizational goals effectively and efficiently, this reason will be the part that cannot be separated in the process of giving encouragement and semnagat so that employees can work better. The purpose of the mission and vision itself is more directed and efficient both in time and purpose of education itself.

\section{METHODS}

The approach used in this study is a qualitative approach using descriptive. Descriptive research methods in research methods that aim to describe the conditions of the research field at the present or when the research is carried out. The data collected is analyzed qualitatively to get meaning from the observed phenomena. Sugiyono (2017) said that the 
research instrument or tool is the researcher himself. This study uses observation methods, interview guidelines and documentation studies. So with regard to the method used, the research instrument used is observation guidelines, interview guidelines and documentation study. The instrument includes responsiveness, adaptability and as a reference for writers in collecting data.

\section{RESULTS AND DISCUSSION}

Progress in Improving Employment Service and Productivity of Human Resources BP2IP Malahayati Acehoffice

The results of the study show that the head program to improve staffing competencies and learning are arranged at the beginning of the school year by the head of the hall and monitored by the development team which includes the annual program and the smester program. not well documented and neat. The planned program is to provide guidance to employees who are in charge of carrying out or providing services routinely in the form of coaching the Preparation of Learning Plans (RPP), implementing learning, conducting classroom monitoring, and procuring teaching aids or media as a supporting tool in the learning process.

Moenir (2014) said service activity is an effort or process by using skills and techniques that can transform materials into something, both in the form of useful goods and services. In connection with these limitations, in management activities can be interpreted, an activity carried out by management is able to change the plan into reality, whether the plan is in the form of an attitude and action plan. So it can be understood that, the activity is an embodiment of ideas (plan) and reality, or between input (input) and output (output).

Implementation of Strategies for Improving Employment Services and Work Productivity of Human Resources BP2IP Malahayati Aceh

Based on the results of the study it can be concluded that the implementation of the improvement of staffing services has begun and has begun to walk with little, this is because the head of the hall who is currently the head of the hall just occupy his new position at BP2IP. The head of the BP2IP hall, Malahayati Aceh, implemented a strategy to improve staffing services and HR productivity by first evaluating the head of the hall and then the head of the hall to evaluate.

However, the results of the interviews found by the researcher before the head of the hall invited the employees to work professionally before the head of the hall met the needs they need include providing a comfortable place to stay within the BP2IP environment, then providing facilities and infrastructure, and the most important is the cost of living for employees or what is called the welfare of employees, this is done by the head of the hall first the first step in the effort increase in staffing services.
Constraints faced in the Process of Implementing Strategies for Improving Employment Services and Work Productivity of Human Resources BP2IP Malahayati Aceh

Based on the results of the study it can be concluded that the obstacles faced by the head of the hall in improving staffing services and work productivity of human resources, such as the head of the hall now this is a new official serving at BP2IP so this is the main obstacle in the head of the hall to improve the ability of employees to work.

Then another challenge is a factor of local culture, ideology, or it can be said with local character that is very different from the previous place of work, so this is a very big challenge to the head of the hall in improving the ability to serve employees, because the head must first understand what what is needed by the employee, the characteristics of the employee itself, and of course must prepare the strate, a program that is truly mature and must be consistent in carrying out what has been agreed.

But the obstacles above are not something that is able to break the spirit of the principal in carrying out the mandate that has been given, barriers are one of the processes for competency to be better in the world of education at this time, and also the obstacles that exist are challenges in maturation and learning process in the future.

\section{CONCLUSION}

The Program for Improving Staffing and Work Productivity of Human Resources BP2IP Malahayati Aceh was prepared at the beginning of each school year by the school development team which included the annual program and the smester program. The planned program is to provide guidance to employees on a regular basis in the form of coaching about the preparation of Learning Implementation Plans (RPP), workshops, trainings, conducting class verification, and conducting evaluations every month.

The implementation of BP2IP Human Resources Employment Services and Productivity Productivity Improvement Strategy Malahayati Aceh began by delivering briefing at the beginning of smester. In carrying out the activities, the head of the hall implemented the family approach, the activities carried out not all of them could be carried out perfectly because of the current leadership period of the head of the hall.

The obstacles faced in the process of implementing the Strategy for Improving Human Resource Employment and Productivity Services of BP2IP Malahayati Aceh is local wisdom that is very different from the previous place. The efforts made to overcome the obstacles that occur are the head of the hall considers it all as challenges that must be faced with a certain vision and mission and teamwork within the organization that is solitary.

\section{REFERENCES}

[1] Moenir. 2014. Education Management. Jakarta: PT Raja Grafindo Persada. 
[2] Sugiyono. 2017. Educational Research Methods Quantitative, Qualitative and $R \& D$ Approaches. Bandung: Alfabeta.

[3] Makawimbang, J. H. 2013. Quality Education

Leadership. Bandung: Alfabeta.

[4] Murniati, and Yusrizal. 2014. Principal Leadership Behavior in Improving Teacher Performance in SD Negeri 2 Lambheun Aceh Besar District. Journal Educational Administration, 3(2), 1-13. 